\title{
IMAGING EVALUATION OF NECK MASSES
}

\section{Professor Sarita Magu}

W other questions.

hich methods are applicable in neck masses diagnostics? What are the anatomical and radiology features of different neck masses? What are the advantages and disadvantages of X-rays and MSCT? What are the advantages of US and MR diagnostics? Current master class gives the answer to these and

Keywords: X-rays, US, MSCT, MRI, neck masses.

\section{АУЧЕВАЯ АИАГНОСТИКА ОБРАЗОВАНИЙ ШЕИ}

\section{Профрессор Сарита Магу}

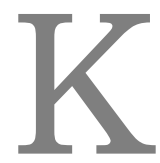

акие методы применяются для диагностики образований шеи? Какие существуют анатомические и рентгенологические особенности разцичных образований шеи? В чем преимущество и недостатки рентгенографии и МCKT? В чем заключается преимущества УЗИ и МР-диагностики? На эти и другие вопросы дает ответ сегодняшний мастер-класс.

КАючевые слова: рентгенография, УЗИ, МСКТ, МРТ, образования шеи.
Sharma Postgraduate Institute of Medical Sciences.

Rohtak (Haryana), India.

\section{Медицинский ин-} ститут посмедиплоиного образования "Шарма".

Рохтак, Индия. 


\title{
А^я просмотра мастер-к^асса перейАите на сайт:
}

https://rejr.ru/twenty-five_nomer/master-class

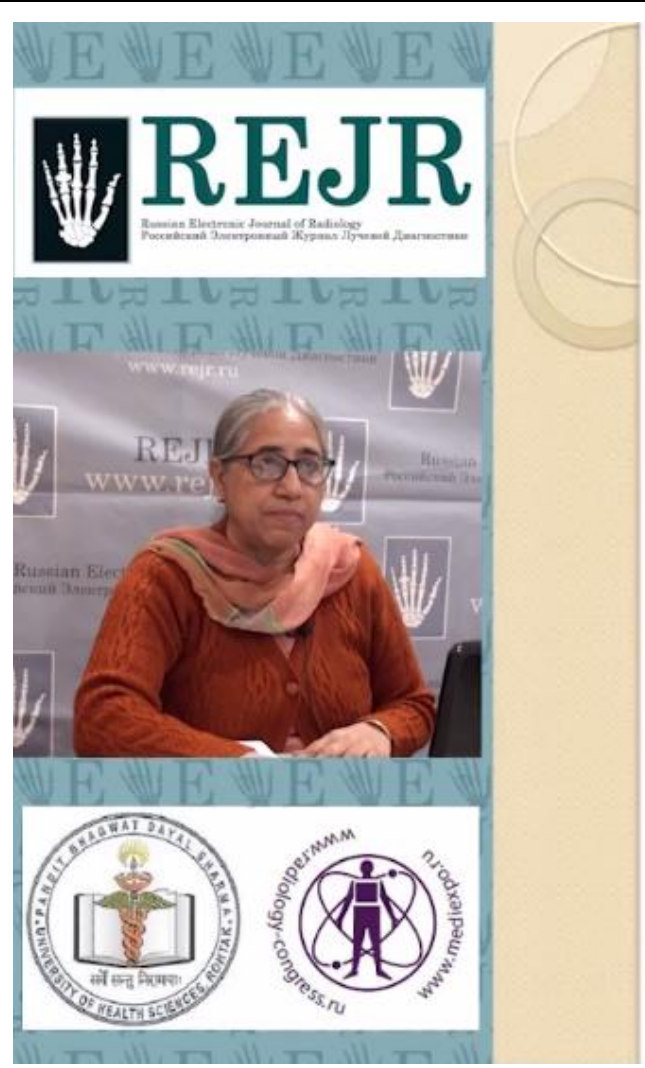

\section{IMAGING \\ EVALUATION OF \\ NECK MASSES}

\author{
Dr. Sarita Magu \\ Senior Professor \\ Department of Radiodiagnosis \\ PGIMS, Rohtak (INDIA)
}

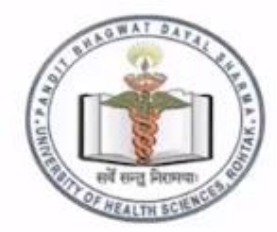

Мастер-к^асс. IMAGING EVALUATION OF NECK MASSES

А^я запуска презентации нажмите на ^юбое место в области презентации, чтобы она загрузилась (если Вы просматриваете журнал в окне браузера, то вначале сохраните журнал к себе на компьютер и откройте его с $л$ о-

кального Аиска, иначе презентация не пойлет).

1) Используйте кнопки влево и вправо в ^евом нижнем углу страницы А^я перемещения по слайдам.

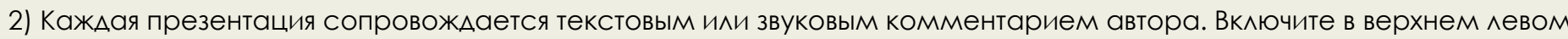
УгАу третью вКАаАКУ - ЗАМЕТКИ. САеАите за текстом автора при переключении презентации на новый слайА. Если презентация сопровожАается звуком, то отрегулируйте уровень звука, нажав на иконку Аинамика.

3) Чтобы вкАючить полноэкранный просмотр презентации Аостаточно нажать ^евой кнопкой мыши на правую нижнюю кАавишу перехола в полноэкранный режим.

Если у Вас не отображается мастер-класс - установите Adobe Flash Player:

http://get.adobe.com/ru/flashplayer/

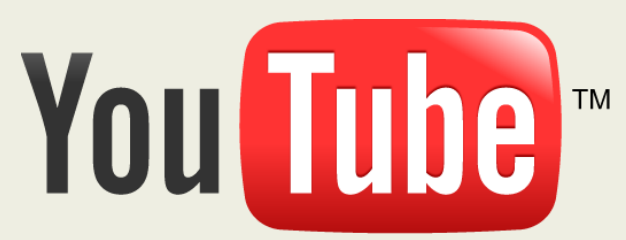

Внимание! Презентация защищена авторскими правами. Полное ияи частичное копирование материала запрещено, без преАварительного согласия авторов. 